\title{
Identification of borax in meatballs at Bandung City, Indonesia
}

\author{
Ira Prima Sari ${ }^{1}$, Fitri April Yanti ${ }^{2}$, Dian Imam Saefullah ${ }^{3}$, Bagus Tri Yunianto \\ 1,4 Medical Laboratory Technology, Rajawali Institute of Health, Indonesia \\ ${ }^{2}$ Department of Physic, Bengkulu University, Indonesia \\ ${ }^{3}$ Department of Sport Science, STKIP Cilacap, Indonesia
}

\begin{abstract}
Borax is a chemical substance that is prohibited from being used as a food additive because of its toxic nature. However, the use of borax is still widely found, one of which is meatballs the most. This study aims to identify the borax content in meatballs. Samples were taken from Ciroyom Market, Bandung City, Indonesia using total sampling with a total of 10 samples of meatballs. The samples were analyzed qualitatively by observing physical conditions and testing using $\mathrm{BaCl}_{2}$ solution. Meanwhile, a quantitative analysis was carried out using a UV-Vis spectrophotometer at a wavelength of $428 \mathrm{~nm}$. The results of the analysis indicated that all samples contain borax. Even the quantitative test using UV-Vis spectrophotometer showed that the highest borax content was found in sample 10, which was 3.672,9 $\mu \mathrm{g} / \mathrm{ml}$.
\end{abstract}

\section{KEYWORDS}

Borax, meatballs, borax toxicology, food health

\author{
ARTICLE INFO \\ Received: 28 June 2021 \\ Accepted: 28 June 2021 \\ Published: 29 June 2021
}

\section{INTRODUCTION}

In Indonesia, there are many types of culinary, one of which is meatballs, a culinary that is very popular and favored by all levels of society. Meatballs are made from raw meat, starch flour, salt, and flavoring (Effendi, 2012). These foods are generally shaped in a round shape. Meatballs with standard ingredients are usually a bit soft so they are not in demand. To deal with this, producers usually add a type of food additive so that the texture becomes chewy. However, many cases that occur are the use of harmful chemicals to produce a chewy texture, such as borax.

Borax has a dangerous impact when consumed by someone because of its toxic nature. Even the toxic effects that can be caused, one of which can cause genetic defects (Pongsavee, 2009). Therefore, based on the Regulation of the Minister of Health Number 1168/Menkes/Per/X/99, borax is included in one of the groups of food additives that are strictly prohibited from using it (Cahyadi, 2008). Even though there are 
regulations regarding the prohibition of the use of borax in food, there are still meatball producers who use this chemical. This is reinforced by research conducted by Panjaitan (2010) which showed that from 10 samples of meatballs tested, 8 samples were identified as containing borax. Another study conducted by Paratmanitya and Aprilia (2016) also showed that the borax content was 2,93\% in the 94 samples tested.

Of course this is an exciting thing to study, especially at Ciroyom Market, Bandung City, Indonesia. In this market, there are a lot of meatball sellers, and it has even become a center for selling meatballs for retail traders. Of course this will be very dangerous, because the number of consumers will be very large when retailers also sell them in their respective places of residence or trading places. The identification of the borax content in the meatballs sold at Ciroyom Market is based on observations which show that the meatballs tend to be whitish in color, have an unnatural smell, and are very chewy. The characteristics of this meatball indicate the presence of borax in it. This refers to the characteristics of meatballs that contain borax as revealed by Mudzkirah (2016), namely the texture is very chewy, the color is more likely to be whitish, the smell is not natural like meat (like there is another smell that appears), and if thrown on the floor it will bounce. higher than meatballs in general. Based on this, it is necessary to conduct research on the identification of borax content in meatballs in the market.

\section{LITERATURE REVIEW}

\section{Borax}

Borax is a chemical compound derived from Boron (B) metal which is usually used as a thickener, preservative, antiseptic, antifungal, wood preservative, toys, and antiseptic in cosmetics (Svehla, 1985; Cahyadi, 2008; Aminah and Himawan, 2009; Platzek, 1985). Krätke, and Schulz, 2010; Craan, Myres, and Green, 1997). This substance is odorless, crystalline, stable, and when dissolved will produce sodium hydroxide and boric acid (Syah, 2005).

\section{Toxic effect of borax}

Borax is a sodium salt with the formula $\mathrm{Na}_{2} \mathrm{~B}_{4} \mathrm{O}_{7} \cdot 10 \mathrm{H}_{2} \mathrm{O}$ and is toxic to all cells in the body (Syah, 2005). The use of borax in foodstuffs is prohibited, this is reinforced by the Regulation of the Minister of Health Number 722/MenKes/Per/IX/88. When borax enters the body, it will be absorbed into the blood and stored in the liver (Suklan, 2002). However, the organ most affected by the presence of borax is the kidney because it is related to the excretory system (Saparinto and Hayati, 2006). Toxic effects that can be caused by the presence of borax in the body are reproductive process disorders, stomach irritation, kidney disorders, liver disorders, testicular disorders, brain disorders, fever, anuria, coma, central nervous system disorders, apathy, depression, cyanosis, low blood pressure, death, anorexia, vomiting, diarrhea, anemia, and convulsions (Suklan, 2002; Widyaningsih and Murtini, 2006; Saparinto and Hidayati, 2006; Hadrup, Frederiksen, and Sharma, 2021; Duydu et al., 2012; Murray, 1998; Jansen, Andersen, and Schou, 1984; Kingma, 1958). Katzung, Masters, and Treveor (2009) and Lipscomb, Swartout, and Teuschler (2004) explained that the consumed borax will react with hydrochloric acid in the stomach to produce boric acid and dissociate into boron. 
Boron that is not metabolized will spread to all compartments of the human body and allow it to react with various biomolecules because it has a high affinity for hydroxyl, amino, and thyol groups, which are all present in all cells.

\section{Characteristics of meatballs containing borax}

According to Mudzkirah (2016) and Widayat (2011), the characteristics of meatballs containing borax are a) having a chewy structure and being harder; b) has a longer shelf life of about 5 days; $c$ ) the texture is very thick, the color is not brown like the use of meat but tends to be whitish; e) the smell feels unnatural, there are other odors that appear; and f) when thrown on the floor will bounce like a ball.

\section{METHODS}

This research was conducted with a qualitative and quantitative approach. Qualitative analysis was carried out to see the physical condition of the meatballs and identify their presence. While the quantitative approach was carried out to measure the level of borax contained in the meatballs.

\section{Sample preparation}

Samples were taken from traders who are active in trading at Ciroyom Market, Bandung City, Indonesia. There were 10 meatball traders and all of them were taken as samples in this study. The meatballs that have been taken are then weighed as much as 5 grams and mashed. The mashed meatballs are soaked in distilled water for 24 hours and filtered.

\section{Qualitative Analysis}

Maharani (2017) explained that a qualitative analysis of borax can be carried out by inserting the borax filtrate into a test tube and adding 0,1 M Barium chloride solution. The presence of a white precipitate indicates the presence of borax in the sample.

\section{Creating standard curves}

Making standard curves refers to Suseno (2019), which is making standard solutions of borax with concentrations of $100 \mu \mathrm{g} / \mathrm{ml}, 500 \mu \mathrm{g} / \mathrm{ml}, 1000 \mu \mathrm{g} / \mathrm{ml}$, and $2000 \mu \mathrm{g} / \mathrm{ml} .0,5 \mathrm{ml}$ of each solution was taken and put into a porcelain cup, then $0,5 \mathrm{ml}$ of $10 \% \mathrm{NaOH}$ solution was added. The cup is then heated until the solution evaporates completely. Then $1,5 \mathrm{ml}$ of $0,125 \%$ curcumin solution was added to the cup and reheated for 3 minutes and cooled. After cooling, the solution was added with $1,5 \mathrm{ml}$ of sulfuric acid and acetic acid (1:1). The solution was stirred until the yellow color disappeared and allowed to stand for 8 minutes. Then added with a little ethanol and filtered using filter paper. The filtrate was put into a $25 \mathrm{ml}$ volumetric flask and added with distilled water up to the mark. The absorbance of each solution was measured using a UV-Vis spectrophotometer at a wavelength of $428 \mathrm{~nm}$. Concentration and absorbance data are then plotted into a graph. 


\section{Measurement of borax levels in meatballs}

Suseno (2019) explained that the measurement of borax levels can be carried out by taking $0,5 \mathrm{ml}$ of prepared sample filtrate and placing it in a porcelain cup. Then added with $0,5 \mathrm{ml} 10 \% \mathrm{NaOH}$ solution and heated to dry and added $0,125 \%$ curcumin solution and stirred and reheated for 3 minutes. After cooling, the solution was added with $1,5 \mathrm{ml}$ of sulfuric acid and acetic acid (1:1), while stirring until the yellow color disappeared and allowed to stand for 8 minutes. Next add a little ethanol and filtered. The filtrate was put into a $25 \mathrm{ml}$ volumetric flask and distilled water was added up to the mark. The absorbance was measured at a wavelength of $428 \mathrm{~nm}$.

\section{RESULTS}

\section{Results of qualitative analysis on samples}

Qualitative analysis was conducted to identify the physical condition and the presence of borax in the sample. The results of the qualitative test using $\mathrm{BaCl}_{2}$ solution produced a white precipitate in all samples. Most of the precipitates formed occurred in sample 1, sample 4, sample 7, sample 9, and sample 10. However, these results indicate that all samples contain borax.

Observation of the physical condition of the meatballs was carried out to see its suitability with the characteristics of the meatballs containing formalin. The results showed that the meatballs were whitish in color and the texture was dense and chewy. When I tried to drop it to the floor, it turned out that most of the meatballs bounced higher than standard meatballs. The results of observations of physical conditions in detail can be seen in Table 1.

Table 1. The results of the observation of the physical condition of the meatball

\begin{tabular}{ccl}
\hline Sample & Test results & \multicolumn{1}{c}{ Observation result } \\
\hline Sample 1 & + & $\begin{array}{l}\text { White in color, the texture is chewy and solid, when } \\
\text { thrown on the floor it bounces }\end{array}$ \\
\hline Sample 2 & + & $\begin{array}{l}\text { Brown in color, chewy texture, when thrown on the floor } \\
\text { does not bounce }\end{array}$ \\
\hline Sample 3 & + & $\begin{array}{l}\text { The color is white, slightly brown, the texture is chewy, } \\
\text { when thrown on the floor it doesn't bounce }\end{array}$ \\
\hline Sample 4 & + & $\begin{array}{l}\text { Very white in color, the texture is chewy and solid, when } \\
\text { thrown on the floor it bounces }\end{array}$ \\
\hline Sample 5 & $+\begin{array}{l}\text { Very white in color, chewy texture, when thrown on the } \\
\text { floor does not bounce }\end{array}$ \\
\hline Sample 6 & $+\begin{array}{l}\text { Very white in color, chewy texture, when thrown on the } \\
\text { floor does not bounce }\end{array}$ \\
\hline Sample 7 & + & $\begin{array}{l}\text { Brown in color, chewy and dense texture, when thrown } \\
\text { on the floor bounces }\end{array}$ \\
\hline Sample 8 & + & $\begin{array}{l}\text { Very white in color, chewy texture, when thrown on the } \\
\text { floor does not bounce }\end{array}$ \\
\hline Sample 9 & + & $\begin{array}{l}\text { Very white in color, the texture is chewy and solid, when } \\
\text { thrown on the floor it bounces }\end{array}$ \\
\hline+ & $\begin{array}{l}\text { It is white and slightly brown in color, the texture is } \\
\text { chewy and solid, when thrown on the floor it bounces }\end{array}$ \\
\hline
\end{tabular}




\section{Standard curve}

The standard curve was made by plotting the concentration data of the standard solution of borax with its absorbance. The data of absorbance measurement results in standard solutions can be seen in Table 2 .

Table 2. The results of the absorbance measurement of the standard solution of borax

\begin{tabular}{cc}
\hline Concentration $(\boldsymbol{\mu g} / \mathrm{ml})$ & Absorbance \\
\hline 100 & 0,3408 \\
500 & 0,6673 \\
1000 & 1,3167 \\
2000 & 2,2985 \\
\hline
\end{tabular}

The results of the data plot in Table 2 will form a straight line and a straight line equation. The $x$-axis represents the concentration value and the $y$-axis represents the absorbance value. The resulting standard curve can be seen in Figure 1. The resulting line equation is $y=0.001 x+0.2111$ where this line equation will be used to calculate the borax content in the meatball sample.

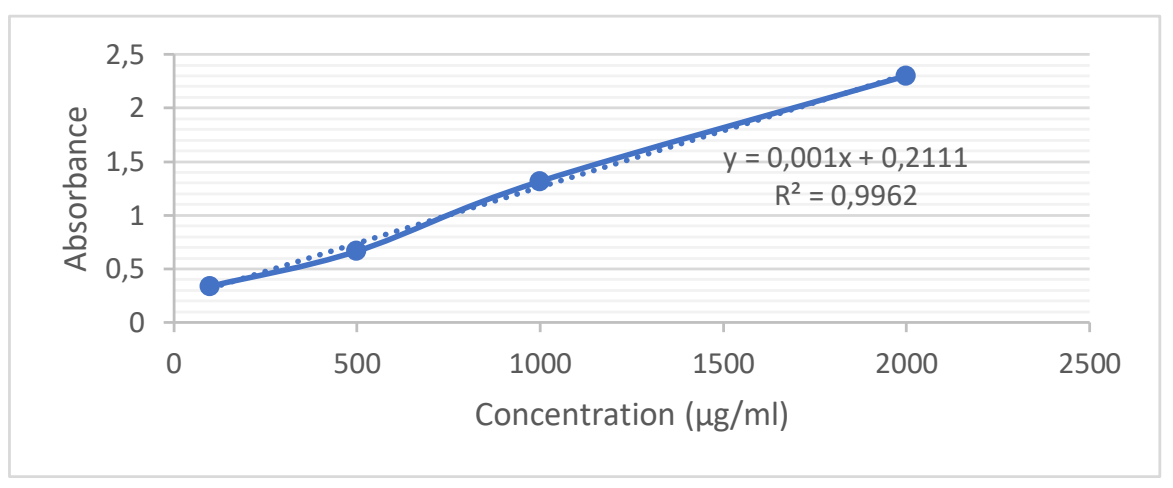

Figure 1. Curve of borax standard solution

\section{The results of the analysis of borax levels in meatballs using a UV-Vis spectrophotometer}

The borax level test in the sample is carried out by calculating the absorbance value and the line equation in Figure 1. The borax level test is carried out only for samples that are indicated to contain high levels of borax. This can be seen from the number of deposits in the qualitative test (see Figure 1). Therefore, the assay test was carried out only on sample 1, sample 4, sample 7 , sample 9 , and sample 10 . The results of the borax level test can be seen in Table 3 .

Table 3. The results of the borax content test in meatballs using a UV-Vis spectrophotometer

\begin{tabular}{cc}
\hline Sample & Borax content $(\boldsymbol{\mu g} / \mathbf{m l})$ \\
\hline Sample 1 & 0,96443 \\
\hline Sample 4 & 0,45391 \\
\hline Sample 7 & 2,36680 \\
\hline Sample 9 & 2,33730 \\
\hline Sample 10 & 3,88390 \\
\hline
\end{tabular}




\section{DISCUSSION}

The addition of $\mathrm{BaCl} 2$ solution in the qualitative test will result in the formation of turbidity or a white precipitate. This can happen if the concentration of borax is high enough in the solution. In the process, a solution of sodium tetraborate (borax) reacts with barium chloride to form a white precipitate of barium metaborate $\left(\mathrm{Ba}\left(\mathrm{BO}_{2}\right)_{2}\right)$, from a fairly concentrated solution. This precipitate is soluble in excess reagent, in dilute acid and ammonium salts (Padmaningrum and Marwati, 2013; Maharani, 2017). These results are also strengthened by the results of qualitative observations using the EASY TES borax reagent kit. Observations on the sample showed that the physical characteristics of the meatballs were related to the presence or absence of borax in the meatballs. This is in accordance with the statement of Widayat (2011) and Mudzkirah (2016) which explain that meatballs containing borax have the characteristics of a chewy and denser structure, longer shelf life (up to 5 days), not brownish color like meat. and tends to be white, smells unnatural, and when thrown on the floor will bounce like a ball.

The results of the qualitative test have actually provided an overview of the abuse of borax in meatballs. $\mathrm{BaCl} 2$ test showed the presence of precipitate in all test samples. The interesting thing from the results of this qualitative test is that there is a difference in the amount of sediment produced which is proportional to the characteristics of the meatball itself. If seen from the observations, samples that have a high level of elasticity and density actually produce more deposits. This happened in sample 1 , sample 4 , sample 7 , sample 9 , and sample 10 . So that these four samples were continued for quantitative testing.

In the quantitative test stage, the standard curve is very decisive. In this study, the equation of the line $y=0.001 x+0.2111$ and the value of $R^{2}=0.9962$. The value of $R^{2}$ is the linearity value of the line where the value closer to 1 will be more linear. Saputra (2016) and Baehaki et al. (2020) explained that the value of $R^{2}$ can be used as an illustration of the feasibility level of the calibration results so as to minimize the level of data errors.

The concentration of borax contained in the samples tested quantitatively showed very high levels with a range of $242.91-3,672.9 \mu \mathrm{g} / \mathrm{ml}$. Of course this is a very high level and at the same time able to explain the reason for the meatballs that are able to bounce quite high when thrown on the floor. High levels of borax will make the meatballs denser and more chewy.

Another fact that is no less important is that all samples were indicated to contain borax. Even though it is very clear that the use of borax in food is strictly prohibited. This has also been regulated in the Regulation of the Minister of Health of the Republic of Indonesia Number 722/MenKes/Per/IX/88 and Regulation of the Minister of Health of the Republic of Indonesia Number 1168/Menkes/Per/X/1999 concerning the use of food additives and food additives that are prohibited. This study also strengthens the results of previous research conducted by Panjaitan (2010) and Paratmanitya and Aprilia (2016) which showed that there was still abuse of borax in food processing carried out by producers.

Borax has a tremendous toxic effect on the body. According to Saparinto and Hidayati (2006), if borax continues to accumulate in the body and exceeds $10-20 \mathrm{~g} / \mathrm{kg}$ body weight in adults and $5 \mathrm{~g} / \mathrm{kg}$ body weight in children, it will cause death. When it enters the body, borax will be absorbed by the blood and stored in the liver, and is cumulative because it is not easily soluble in water and is carcinogenic. Frequent consumption of 
foods containing borax will cause brain, liver and kidney disorders. Even in large quantities, borax can cause anuria, coma, depression, decreased blood pressure and even death (Widyaningsih and Murtini, 2006). This is because borax taken orally will interact with hydrochloric acid in the stomach and turn into boric acid and dissociate into boron. Boron will be well absorbed by the intestinal villi in the gastrointestinal tract. Furthermore, boron will be distributed to all tissues in the body (Lipscomb, Swartout, and Teuschler, 2004; Katzung, Masters and Treveor, 2009). Borax is not metabolized in the body, this is because it takes a lot of energy (523 kJ/Mol) to break the bonds between oxygen and boron. Borax in the form of boric acid is not dissociated and will be distributed in all tissues. Borax will be excreted $>90 \%$ through urine in a form that is not metabolized. In addition to being passed through urine, borax is also excreted in minimal amounts through saliva, sweat and feces (Adinugroho, 2013). The continuous entry of borax will cause damage to the liver cell membranes, followed by damage to the liver parenchyma cells. This happens because the active group of borax $B-O-B(B=O)$ will bind to unsaturated proteins and lipids, causing lipid peroxidation. Lipid peroxidation can damage cell permeability because the cell membrane is rich in lipids, as a result all substances can enter and leave the cell (Adinugroho, 2013).

\section{CONCLUSION}

Based on the research that has been done, it can be concluded that the meatballs sold at Ciroyom Market are indicated to contain borax. The highest borax content was in sample 10 with a total of $3.672,9$ $\mu \mathrm{g} / \mathrm{ml}$. These results have corroborated previous research which stated that there was still misuse of borax in the processing of foodstuffs. Of course this needs to be a concern for related institutions, such as the Food and Drug Supervisory Agency of the Republic of Indonesia, because this is directly related to processed food products consumed by the public. So that it can increase the risk of health problems in the community.

This research is still descriptive in nature so it cannot conclude about the complete picture of the widespread abuse of borax in meatballs. The limited time of the study made this study only focus on the analysis of levels and was carried out in one location only. However, a more in-depth and extensive study needs to be done. Several factors also need to be researched, such as the level of knowledge of the community, traders, and producers. So that all factors can be used as a collection of interconnected data to obtain effective and efficient solutions, especially for related supervisory agencies.

\section{REFERENCES}

Adinugroho, N. (2013). Pengaruh pemberian boraks dosis bertingkat teerhadap perubahan gambaran makroskopis dan mikroskopis hepar selama 28 hari. Semarang: Fakultas Kedokteran, Universitas Diponegoro.

Aminah M.S. \& Himawan H. (2009). Bahan-bahan berbahaya dalam kehidupan. Bandung: Salamandani.

Baehaki, F., Rudibyani, R. B., Aeni, S. R. N., Perdana, R., and Aqmarina, S. N. (2020). Utilization of salacca zalacca seeds as chromium(vi) adsorbents. Periodico Tche Quimica, 17(34), 381-389.

Cahyadi, W. (2008). Analisis dan aspek kesehatan bahan tambahan pangan $2^{\text {nd }}$ ed. Jakarta: Sinar Grafika.

Craan, A.G., Myres A.W., Green D.W. (1997). Hazard assessment of boric acid in toys. Regul Toxicol Pharmacol, 26(3), $271-280$ 
Duydu, Y., Başaran N., Üstündağ, A., Aydın, S., Ündeğer, Ü., Ataman, O.Y., Aydos, K., Düker, Y., Ickstadt, K., Waltrup, B.S., Golka, K., Bolt H.M. (2012). Assessment of DNA integrity (COMET assay) in sperm cells of boron-exposed workers. Arch Toxicol, 86(1), 27-35.

Effendi, H.M.S. (2012). Teknologi pengolahan dan pengawetan pangan. Bandung: Alfabeta.

Hadrup, N., Frederiksen, M., \& Sharma, A.K. (2021). Toxicity of boric acid, borax and other boron containing compounds: A review. Regulatory Toxicology and Pharmacology, 121. https://doi.org/10.1016/j.yrtph.2021.104873

Jansen J., Andersen J., Schou J.S. (1984). Boric acid single dose pharmacokinetics after intravenous administration to man. Arch Toxicol, 55(1), 64-67.

Katzung, B.G., Masters S.B., Trevor A.J. (2009). Basic and clinical pharmacology (terjemahan), Edisi ke-11. Jakarta: EGC. Kingma, H. (1985). The pharmacology and toxicology of boron compounds. Can Med Assoc J., 78(8), 620-622.

Lipscomb, J., Swartout, J., \& Teuschler, L. (2004). Toxicological review of boron and compounds. Washington D.C: US Environmental Protection Agency.

Maharani, L. D. (2017). Analisis kualitatif boraks pada beberapa makanan yang beredar di Kecamatan Jebres Kota Surakarta. Surakarta: Fakultas IImu Kesehatan, Universitas Setia Budi.

Mudzkirah, I. (2016). Identifikasi penggunaan zat pengawet boraks dan formalin pada makanan jajanan di kantin UIN Alauddin Makassar. Makassar: UIN Alauddin.

Murray, F.H. (1998). A comparative review of the pharmacokinetics of boric acid in rodents and humans. Biol Trace Elem Res, 66, 31-341.

Padmaningrum, R. T., \& Marwati S. (2013). Tester kit untuk uji boraks dalam makanan. Jurnal Penelitian Saintek, 10(1), 24-33.

Panjaitan, L. (2010). Pemeriksaan dan penetapan kadar boraks dalam bakso di Kota Madya Medan Sumatra Utara. Medan: Fakultas Farmasi, Universitas Sumatera Utara.

Peraturan Menteri Kesehatan Republik Indonesia Nomor 1168/Menkes/Per/X/1999 Tentang Perubahan atas Peraturan Menteri Kesehatan Nomor 722/Menkes/Per/IX/1988 tentang Bahan Tambahan Makanan.

Peraturan Menteri Kesehatan Republik Indonesia Nomor 722/Menkes/Per/IX/1988 tentang Bahan Tambahan Makanan.

Platzek T., Krätke R., Schulz C. (2010). Cosmetic products: safety aspects. Bundesgesundheitsblatt Gesundheitsforschung Gesundheitsschutz, 53(6), 610-614.

Pongsavee, M. (2009). Effect of borax on immune cell proliferation and sister chromatid exchange in human chromosomes. J. Occup. Med.Toxicol., 4(27). https://doi.org/10.1186/1745-6673-4-27

Safarinto, C \& Hidayati, D. (2006). Bahan tambahan pangan. Yogyakarta: Kanisius.

Saputra, B.M. (2016). Pengaruh $\mathrm{HNO}_{3}$ dan $\mathrm{NaOH}$ pada analisis $\mathrm{Cr}(\mathrm{III})$ menggunakan asam tanat secara spektrofotometri ultra ungu-tampak. Bandar Lampung: Fakultas Matematika dan Ilmu Pengetahuan Alam, Universitas Lampung.

Suklan, H. (2002). Apa dan mengapa boraks dalam makanan. Penyehatan Air dan Sanitasi (PAS), 4(7).

Suseno, D. (2019). Analisis kualitatif dan kuantitatif kandungan boraks pada bakso menggunakan kertas turmerik, FT-IR spektrofotometer dan spektrofotometer Uv-Vis. Indonesian Journal of Halal, 1-9. https://doi.org/10.14710/HALAL.V211.4968

Svehla, G. (1985). Vogel: Analisis anorganik kualitatif. 5th ed. Jakarta: PT Kalman Media Pusaka.

Syah, dkk. (2005). Manfaat dan bahaya bahan tambahan pangan. Bogor: Himpunan Alumni Fakultas Teknologi Pertanian IPB.

Widayat, D. (2011). Uji kandungan boraks pada bakso. Jember: Fakultas Kesehatan Masyarakat, Universitas Jember. Widyaningsih \& Martini (2006). Alternative pengganti formalin pada produk pangan. Surabaya: Trubus Agrisarana. 